\title{
THE INFLUENCE OF TRAIN-INDUCED GROUND MOTION IN ASSESSMENTS OF DYNAMIC IMPACT ON STRUCTURES
}

\author{
K. NIELEPKOWICZ ${ }^{1}$, A. BĄKOWSKA ${ }^{2}$, M. MAŚLAKOWSKI ${ }^{3}$
}

\begin{abstract}
In this study, the issue of intensity of cargo train-induced soil vibrations is presented. Oscillations were measured in Warsaw-Rembertow location with application of set of seismic receivers. The analysis concerns the ground vibration differentiation issue, depending on considered direction of oscillation propagation plane. Statistic distribution of vibration intensity for directions in 3-D space were done. The issue of potential effect on engineering structures of recorded vibrations was raised. The impact based on Scale of Dynamic Effects standard was estimated in the article. Vibration intensity results were also compared with classification according to the Swiss Standard.
\end{abstract}

Keywords: vibration intensity, surface waves, rail traffic, Scale of Dynamic Effects, Swiss Standard

\section{INTRODUCTION}

Rail traffic is one of the largest sources of dynamic effects in urban areas. Most of these effects have a character of surface waves (Rayleigh and Love), microseismic waves and direct waves [1-4]11. Their propagation occurs in the superficial soil strata, not deeper than half of the wavelength. They stand out on the seismograms from other types of waves due to their higher intensity and lower

\footnotetext{
${ }^{1}$ MSc., Eng., Warsaw University, Faculty of Geology, Żwirki i Wigury 93, 02-089 Warsaw, Poland, e-mail: k_nielepkowicz@student.uw.edu.pl

${ }^{2} \mathrm{PhD}$., Warsaw University, Faculty of Geology, Żwirki i Wigury 93, 02-089 Warsaw, Poland, e-mail: anna.bakowska@.uw.edu.pl

${ }^{3}$ PhD., Eng., Warsaw University of Technology, Faculty of Civil Engineering, Al. Armii Ludowej 16, 00-637 Warsaw, Poland, e-mail: m.maslakowski@il.pw.edu.pl
} 
propagation velocity than body waves. More than $60 \%$ of energy, generated during work of the source of vibration, is converted into surface waves [4-6] and this also applies to rail traffic.

The subject of ground vibration caused by means of transport was raised by many authors, i.e. [1, 2 , 6-12]. Their results shown substantial differences in measured vibration intensity with modification of survey conditions (sort of moving object, velocity, weight, distance to object, type of receiver and the other factors). The importance of vibration issue in civil engineering constantly increase due to dynamic development of urban areas, especially in terms of rail transport, earth works and wind effects. The question of damping of this vibrations have an increasing importance to constructors. The other approach treat excessive ground motion as an environmental pollution harmful for people [6]. The issue of oscillation impact on building residents was raised in standards in many developed countries, like Australia, Germany, Switzerland UK, USA [3]. Threshold values of annoying vibration were established as significantly lower than those damaging structures $[1,3,12,13]$.

The main objective of field investigations is obtaining of soil vibration intensity data (amplitude, acceleration, frequency values), characteristic for various means of urban transport. Received data can be further applied for laboratory shear strength tests of soils subjected to cyclic loading or numerical modelling of construction dynamic behaviour. This study presents comparison of vibration intensity measurements between two passages of cargo trains in different distance to measurement line with seismic receivers. The results are presented on the background of standards referring to the issue of vibration effects on buildings.

\section{METHODOLOGY - LOCATION AND MEASUREMENT CHARACTERISTICS}

The research field was situated in Warsaw, in the Rembertow district, on the side of railway lines No 002 and No 448, about $1 \mathrm{~km}$ west of the Warsaw-Rembertow railway station (Fig. 1). The site was selected due to relatively frequent railway traffic (average 1 train passage in five minutes) and location in the less urbanized area, which allowed for convenient installation of equipment and minimizing impact of the other sources of paraseismic vibrations. The superficial subsoil on the site is composed from sandy stratum up to $2 \mathrm{~m}$ depth, below which is situated layer of varved-clay [14]. Railway embankment, composed of soil aggregates, is 0,6 m high (Fig. 2).

To record train-induced vibrations, ABEM Terraloc Pro seismograph was applied. The instrument can be used for engineering, geotechnical and geological purposes, including refraction and reflection surveys as well as vibration measurements [15]. 
The measuring set was arranged in parallel configuration in relation to railway tracks (Fig. 1, 2). One cable (115 m long) with 24 channels was connected to the instrument. Seismic receivers (geophones) were arranged along the measurement line $(35 \mathrm{~m})$ and grouped into 8 channels with $5 \mathrm{~m}$ interval among all channels. The eigen-frequency of geophones amounts to $9,8 \mathrm{~Hz}$. The line with receivers was set on the side of railroads, $7 \mathrm{~m}$ from the longitudinal axis of the first track.

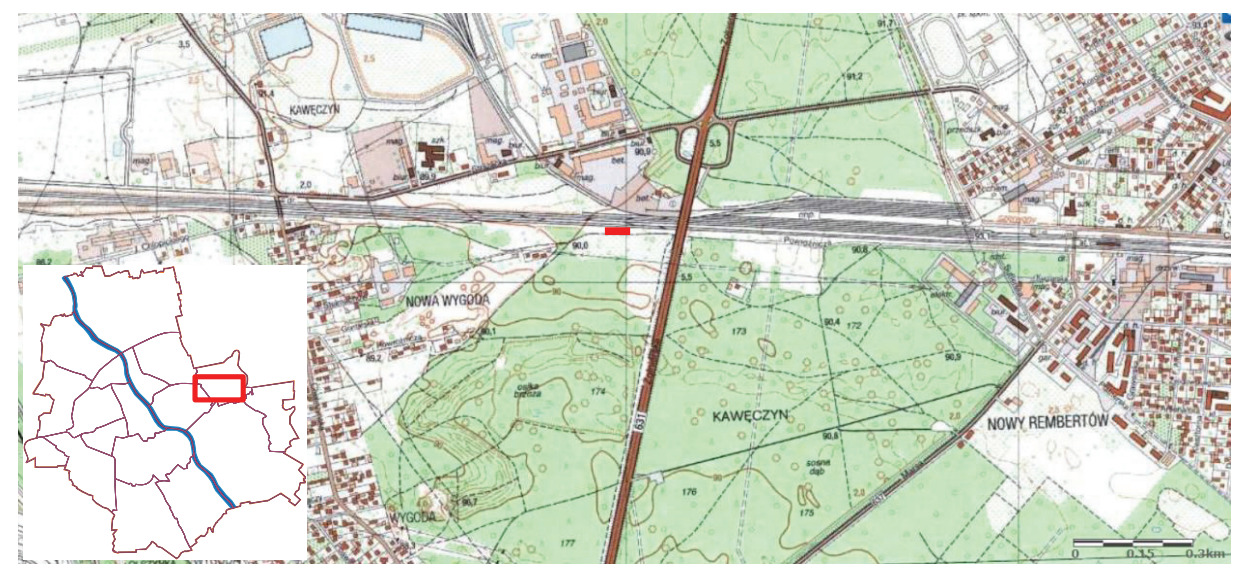

Fig. 1. Location of measurement line [mapy.geoportal.gov.pl]

Each channel consisted of three geophones: one vertical and two horizontal receivers. In each group, first geophone (horizontal) was turned into perpendicular direction to tracks, second (horizontal) parallely to tracks and vertical was the third one. Basing on this, local coordination systems were constructed for each channel - group of receivers. Three coordinate axes were adopted: $\mathrm{X}-$ for direction of first receiver (horizontal), $\mathrm{Y}$ - for direction of second receiver (horizontal) and $\mathrm{Z}-$ for vertical direction (Fig. 2).

In measurements, the method of passive seismic record of surface waves was applied. This means, that seismic data considered in this paper are related to superficial stratum of the subsoil, as it was introduced in Chapter 1 (surface waves). During the measurements, notch filter at value $50 \mathrm{~Hz}$ of frequency was applied in the instrument, what is connected with conventional power line frequency in Poland. This could be an additional factor to influence measured values of vibration frequency. 


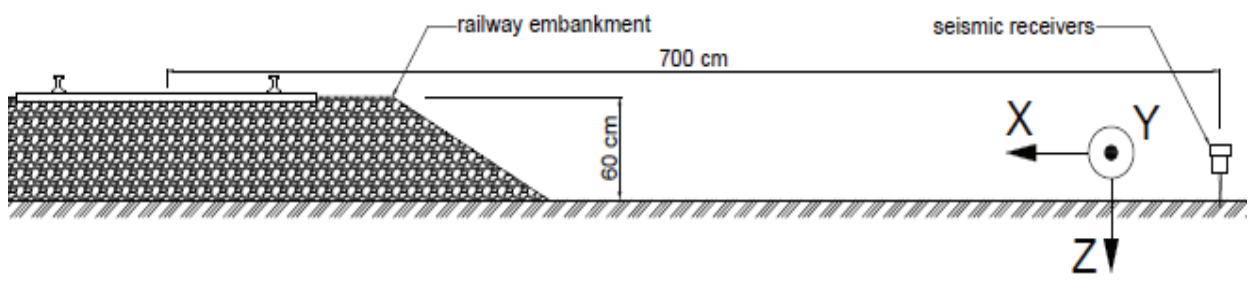

Fig. 2: The arrangement of measuring set in relation to proximate railway track, with imposed coordinate system

\section{DATA ACQUISITION AND PROCESSING}

The SeisTW program built-in into the aforementioned instrument was used to record train-induced vibration data. For further analysis, the data from four measurements were selected, that are most valuable in terms of intensity, where train passage impact was the most distinct in comparison with the seismic noise (Fig. 3). Measurement methodology and characteristics include: amplitude value measured in $\mathrm{mm} / \mathrm{s}$ (velocity amplitude), $100 \mu \mathrm{s}$ of sampling interval, 65536 or 131072 number of samples (6,5 - 13,0 s time of registration) and 24 seismic records: one from each receiver.

The Reflex 2D-Quick and Reflexw were used for data processing. Vibration intensity was determined by using peak particle velocities (PPV), as it could be applied for man-made vibration $[1-3,7,12$, 13]. Peak velocity amplitudes of vibrations with their corresponding frequencies were read off with application of "profile sum spectrum/histogram" tool, derived from Reflexw program. PPV values have been received in time domain and frequency values in frequency domain, after Fast Fourier Transform (FFT) of each peak velocity impulse.

For calculations of vibration intensity parameters, a presumption of sinusoidal, harmonic character of received surface wave was adopted, like it was done in cited literature [10, 16, 17]. Values of amplitude and acceleration have been deduced from gained velocities and frequencies of the most intense vibrations, according to the methodology of PPV.

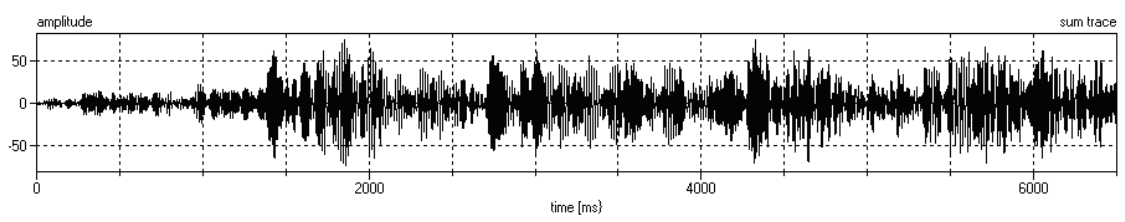



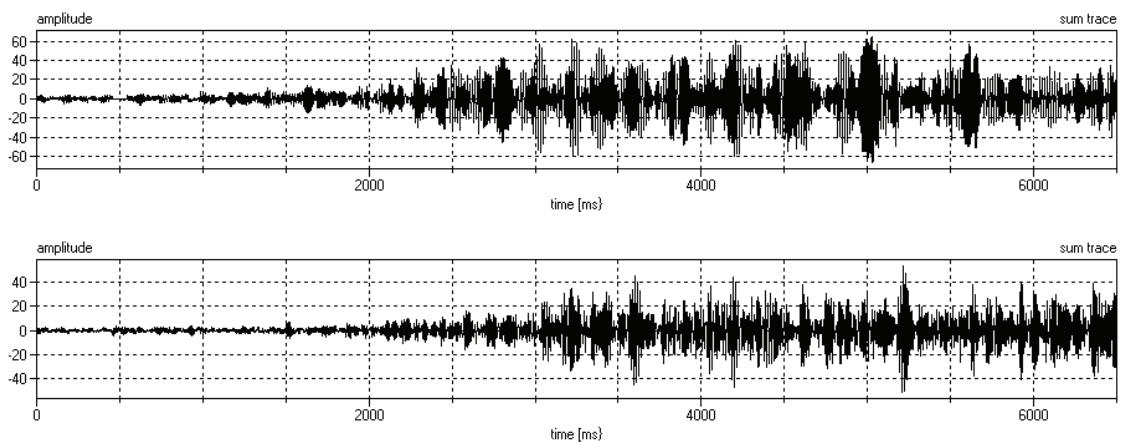

Fig. 3. Records of vibration intensity from selected geophones - channels: 4., 5., 6., direction: X (particle velocity amplitude in $\mathrm{mm} / \mathrm{s}$ )

The circular frequency $(\omega)$ is calculated for assumed value of frequency, corresponding to peak particle velocity of selected impulse. It is defined by the following formula:

$$
\omega=2 \cdot \Pi \cdot \mathrm{f}
$$

where:

$\Pi$ - PI number, $\mathrm{f}-$ impulse frequency $[\mathrm{Hz}]$.

The displacement amplitude (A) is deduced from integration of measured PPV value in the time domain. The acceleration amplitude (a) is the derivative of measured PPV value in the time domain. These parameters can be calculated for a selected impulse with the following formulas [18]:

$$
\begin{gathered}
A=\frac{v}{\omega} \\
\mathrm{a}=\mathrm{v} \cdot \omega
\end{gathered}
$$

where:

$\mathrm{v}$ - peak particle velocity $[\mathrm{mm} / \mathrm{s}], \omega-$ circular frequency $[\mathrm{rad} / \mathrm{s}]$.

The acquisitioned set of data was characterised by typical parameters: average, standard deviation and variability coefficient. For the aim of defining intensity of ground motion, statistic parameters of amplitude, velocity, acceleration and frequency values have been calculated. Average values for each parameter have been calculated, divided into three selected directions (X, Y, Z), according to assumed local coordination systems (Fig. 2). 
On the basis of equations written above $(3.1,3.2,3.3)$ there was collected a set of vibration intensity and frequency data, what allowed for characterizing train-induced dynamic effects.

\section{RESUltS}

\subsection{VIBRATION INTENSITY}

The results are derived from measurements carried on two selected train passages: first, $7 \mathrm{~m}$ away from the line ( $1^{\text {st }}$ track) and second, $25 \mathrm{~m}$ away from the line ( $5^{\text {th }}$ track). Heavy cargo trains, travelling with $25 \mathrm{~km} / \mathrm{h}$ speed, are considered. For each train passage two records were made, what allowed for gathering $48 \mathrm{PPV}$ values (16 in each of X, Y, Z directions in 3-D space). The following study is a comparison between this two passages in terms of decrease ground motion intensity with the distance from the source of vibrations.

The results of in-situ measurements are summarized in the table below (Tab. 1) and on a set of graphs, with application of a boxplot method (Fig. 4). The average values of peak particle velocities (maximum velocity amplitudes of vibrations on each trace) of proximate train passage ( $7 \mathrm{~m}$ to source) are: in X-direction $49,2 \mathrm{~mm} / \mathrm{s}$, in Y-direction $34,5 \mathrm{~mm} / \mathrm{s}$ and in Z-direction 22,0 mm/s (Fig. 4a). The average for three directions is equal to $35,2 \mathrm{~mm} / \mathrm{s}$. For comparison, PPV values achieved by distant train passage ( $25 \mathrm{~m}$ to source) are respectively: in X-axis $8,9 \mathrm{~mm} / \mathrm{s}$, in $\mathrm{Y}$-axis $6,2 \mathrm{~mm} / \mathrm{s}$, and in Zaxis $6,3 \mathrm{~mm} / \mathrm{s}$ (Fig. $4 \mathrm{~b}$ ). The average for three directions is equal to $7,1 \mathrm{~mm} / \mathrm{s}$.

As the next parameter, the frequency values corresponding to peak particle velocities were determined. On the basis of measured velocity and frequency values, there were calculated the other parameters: displacement amplitude and acceleration of soil particles (Equations: 3.2 and 3.3).

The comparison between both train passages shown, that intensity of vibrations induced by proximate train passage, is about 20 times higher than those induced by distant train (with similar values of displacement amplitude). These results shown strong dependence of train-induced ground motion intensity in relation to direction of measurements. 
Tab. 1: Statistical parameters of vibration intensity measurements and calculations for $\mathrm{N}=16$ tests $\ddot{\mathrm{x}}$ - arithmetical mean; $\mathrm{s}$ - standard deviation; min, $\max$ - minimum and maximum values

\begin{tabular}{|c|c|c|c|c|c|c|c|}
\hline \multirow{3}{*}{$\begin{array}{l}\text { Vibration } \\
\text { intensity } \\
\text { parameter }\end{array}$} & \multirow{3}{*}{$\begin{array}{l}\text { Statistical } \\
\text { parameter }\end{array}$} & \multicolumn{3}{|c|}{ Near train } & \multicolumn{3}{|c|}{ Far train } \\
\hline & & \multicolumn{3}{|c|}{ Direction } & \multicolumn{3}{|c|}{ Direction } \\
\hline & & $\mathrm{X}$ & $\mathrm{Y}$ & $\mathrm{Z}$ & $\mathrm{X}$ & $\mathrm{Y}$ & $Z$ \\
\hline \multirow{4}{*}{$\begin{array}{c}\text { velocity } \\
\text { amplitude } \\
\text { (v) }[\mathrm{mm} / \mathrm{s}]\end{array}$} & $\ddot{\mathrm{x}}$ & 49,2 & 34,5 & 22,0 & 8,9 & 6,2 & 6,3 \\
\hline & $\mathrm{s}$ & 14,0 & 12,9 & 11,5 & 1,9 & 1,1 & 1,4 \\
\hline & $\min$ & 27,5 & 19,0 & 13,5 & 6,2 & 4,2 & 4,3 \\
\hline & $\max$ & 74,0 & 64,0 & 58,5 & 12,4 & 8,7 & 9,2 \\
\hline \multirow{4}{*}{$\begin{array}{l}\text { frequency } \\
\text { (f) }[\mathrm{Hz}]\end{array}$} & $\ddot{x}$ & 91,8 & 100,9 & 98,9 & 20,3 & 18,3 & 14,2 \\
\hline & $\mathrm{s}$ & 14,6 & 16,7 & 14,8 & 8,9 & 8,7 & 6,8 \\
\hline & $\min$ & 74,0 & 59,0 & 67,0 & 8,5 & 9,0 & 9,0 \\
\hline & $\max$ & 116,0 & 118,0 & 117,0 & 31,0 & 31,0 & 29,5 \\
\hline \multirow{4}{*}{$\begin{array}{l}\text { displacement } \\
\text { amplitude } \\
\text { (A) }[\mathrm{mm}]\end{array}$} & $\ddot{\mathrm{x}}$ & 0,089 & 0,056 & 0,038 & 0,083 & 0,064 & 0,079 \\
\hline & $\mathrm{s}$ & 0,035 & 0,023 & 0,026 & 0,037 & 0,025 & 0,025 \\
\hline & $\min$ & 0,041 & 0,027 & 0,020 & 0,037 & 0,032 & 0,032 \\
\hline & $\max$ & 0,151 & 0,097 & 0,119 & 0,174 & 0,103 & 0,129 \\
\hline \multirow{4}{*}{$\begin{array}{l}\text { acceleration } \\
\text { amplitude } \\
\text { (a) }\left[\mathrm{mm} / \mathrm{s}^{2}\right]\end{array}$} & $\ddot{\mathrm{x}}$ & 27717 & 21867 & 13198 & 1179 & 744 & 593 \\
\hline & $\mathrm{s}$ & 6560 & 8862 & 5447 & 712 & 431 & 404 \\
\hline & $\min$ & 16415 & 8954 & 7653 & 400 & 290 & 254 \\
\hline & $\max$ & 38092 & 42223 & 28670 & 2376 & 1531 & 1561 \\
\hline
\end{tabular}

a) near train
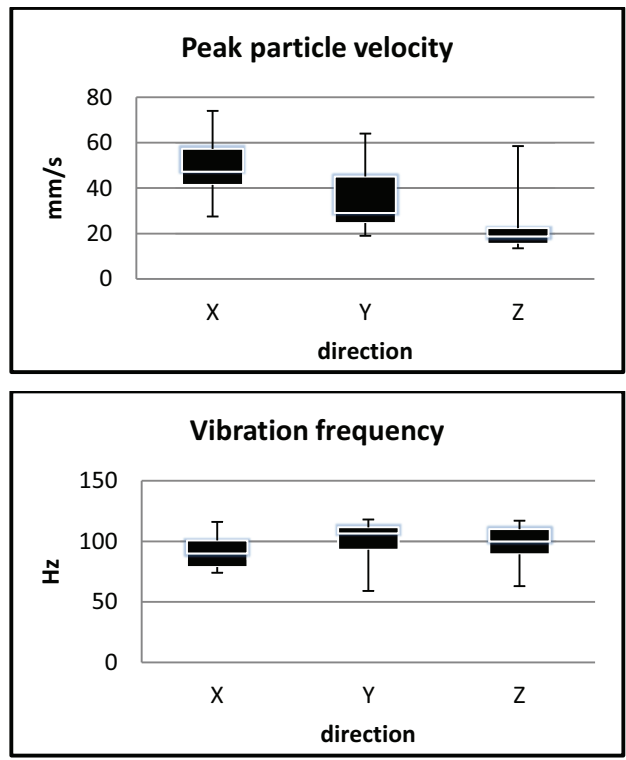

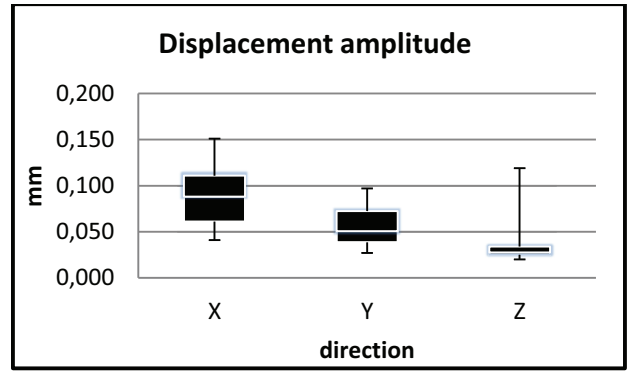

Acceleration amplitude

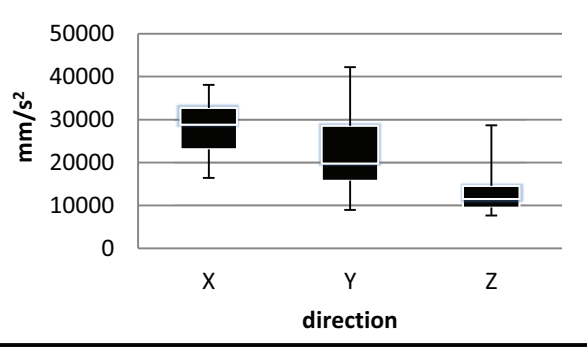


b) far train
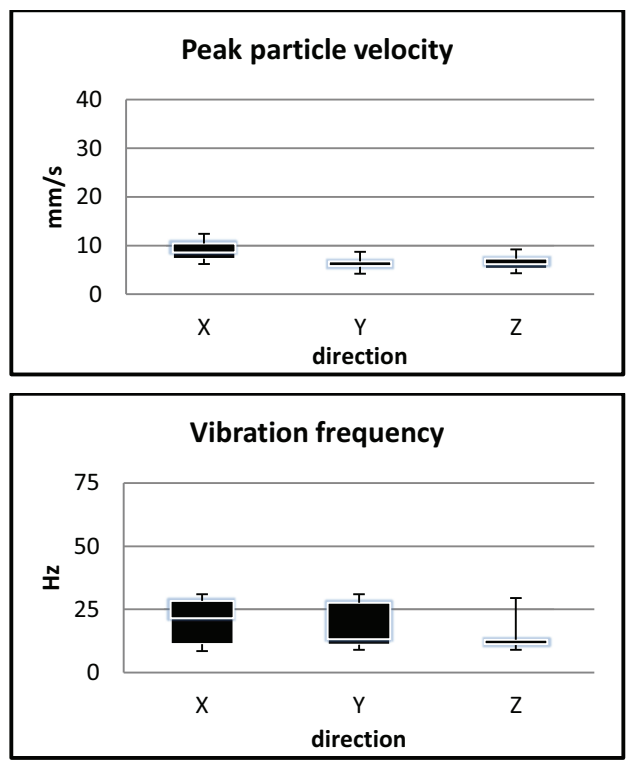

\section{Displacement amplitude}
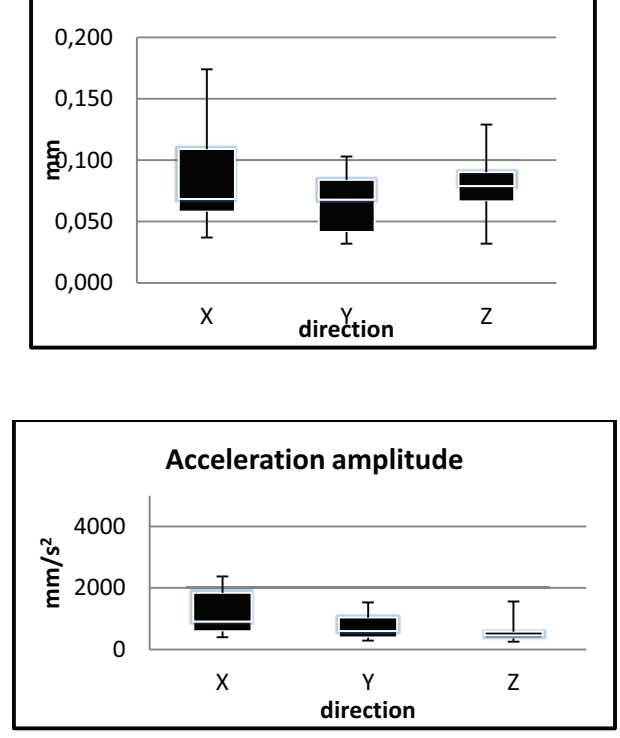

Fig. 4. Comparison of measurement results between two passages of cargo train: a) near train, b) far train. Box plot values: minimum $-1^{\text {st }}$ quartile - median $-3^{\text {rd }}$ quartile - maximum.

The strongest vibrations can be recorded perpendicularly to the rail line (X-direction - Fig. 2). It should be noted, that the highest values of PPV have been recorded after reaching rail connections by the train wheels. The moments of hitting in connections can be distinctly seen on some seismograms, especially recording oscillations in X-direction (Fig. 3). 


\subsection{Potential influence on STRUCtures}

In Poland, SWD standard classification ("Scale of Dynamic Effects") [18] presents the possible impact of man-made vibrations on buildings. The influence is qualified in division for 5 categories, with increasing damage potential: from zone I - no impact on construction, to zone $\mathrm{V}$ - possible destruction of building. Vibration intensity is classified on the basis of velocity amplitude (PPV) $[\mathrm{mm} / \mathrm{s}]$ or acceleration amplitude $\left[\mathrm{mm} / \mathrm{s}^{2}\right]$ against frequency $[\mathrm{Hz}]$, as it is shown in Figure 5.

The results of in-situ measurements conducted in Warsaw-Rembertow presented on graph (Fig. 5) are divided into two groups: for proximate train (greater markers) and for distant train (lower markers). Moreover, three directions of wave propagation for each train were distinguished. Distribution of peak particle velocities measurements confirms the high vibration level induced by near $(7 \mathrm{~m})$ train passage. As it is located in the fifth zone, according to SWD classification, probable effect on nearby buildings may be harmful. Far train passage impact is one order of magnitude lower (in terms of acceleration), but still high and causing potential damage.

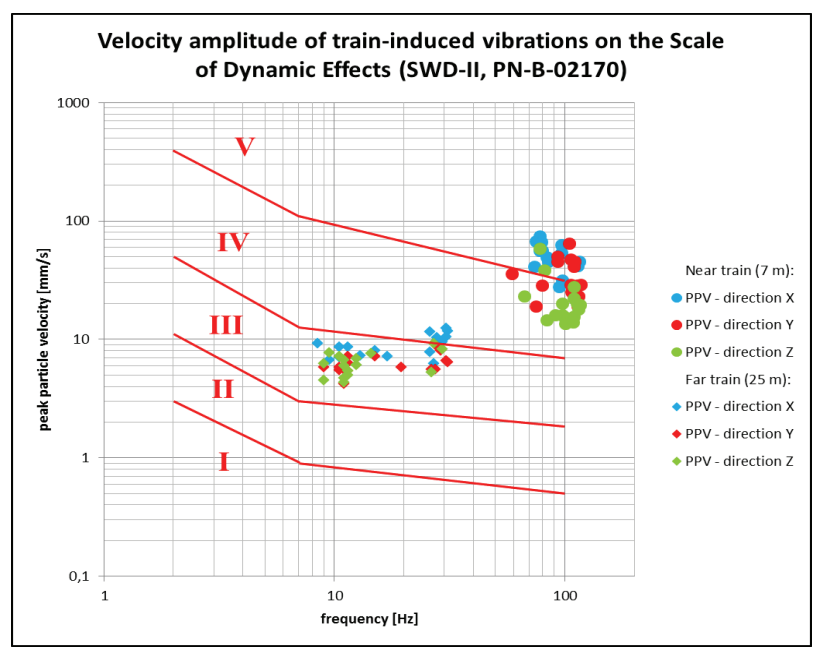

Fig. 5. Comparison of both train passages potential impact on buildings, on the background of Scale of Dynamic Effects, adapted from Polish Standard [18] 


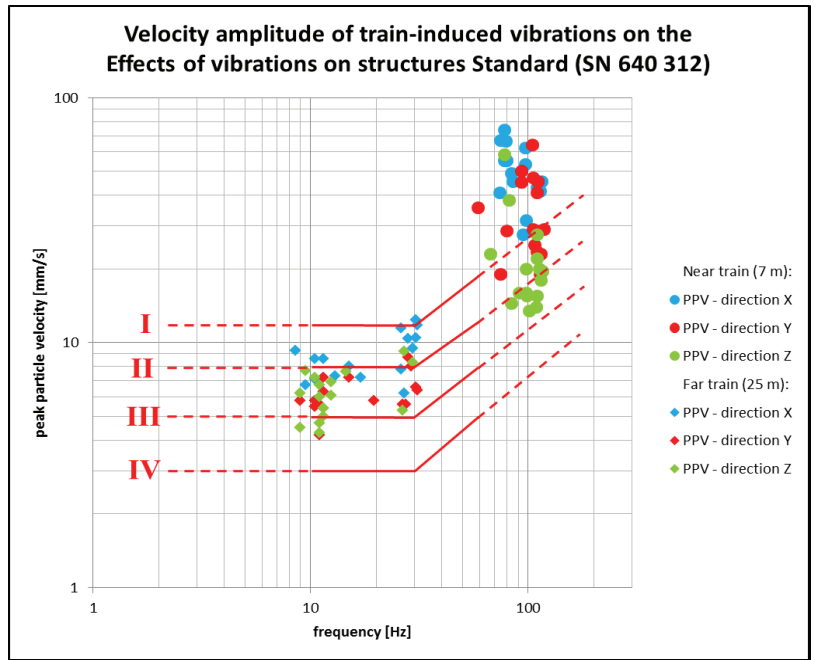

Fig. 6: Comparison of both train passages potential impact on buildings, on the background of classification, adapted from Swiss Standard [20]

On the other hand, Swiss standard classification ("Effects of Vibration on Construction") $[19,20]$ introduces the possible impact of traffic vibrations on buildings in the different context. The borders in the PPV - frequency space are set for the various types of structures with different durability for vibrations. The lines sketched on the Figure 6 refer to all types of man-made vibration, except of blasting-induced ones (higher limits) [19]. Each border is the lower limit of possible construction damage, which is the equivalent of the border between II and III zone in Polish Standard [18].

The influence is qualified by 4 guide values, each dedicated for different type of structures: from IV - sensitive and heritage buildings, to I - reinforced steel and concrete constructions. Vibration intensity is classified on the basis of peak particle velocity $[\mathrm{mm} / \mathrm{s}]$ against frequency $[\mathrm{Hz}]$, as it is shown in Figure 6. It should be noticed, that the guidelines are extended from the frequency of $10 \mathrm{~Hz}$ to $60 \mathrm{~Hz}$. It is the interval of the most common occurring man-made vibration. In this study, both train-induced ground motion intensity results are compared. The results of measurements were presented (Fig. 6) on the background of Swiss classification, analogically to the Figure 5, with three distinguished directions. Most of PPV values recorded for near train exceeded the line of predicted damage of reinforced structures, which is a confirmation of high intensity of ground motion. According to this standard, also the far train passage can be considered as harmful to wooden and brickwork structures [19]. To summarize, the Swiss Standard is considered to be substantially more conservative [3] than Polish Standard in terms of permissible level of ground motion. 


\section{CONCLUSIONS}

The in-situ measurements allowed for characterizing vibration generated by passages of cargo trains in different distances to measurement line. These seismic records demonstrated surface-wave character and high intensity of oscillations. The vibration intensity codes of Polish and Swiss Standards were compared and the recorded measurements on the background of these classifications were presented. The remarks on recorded ground motion intensity and its potential dynamic impact on engineering structures subjected to recorded train-induced vibrations are:

1. Difference in soil particle velocity for three selected directions of surface wave propagation is very distinct for proximate train passage ( $7 \mathrm{~m}$ to measurement line) (Fig. 4a). The highest measured ground motion intensity corresponds to record in horizontal plane, in perpendicular direction to railway (average value: 49,2 mm/s). Oscillations registered in vertical plane are 2-times lower than those in horizontal. However, for distant train passage ( $25 \mathrm{~m}$ to measurement line), aforementioned relationships are significantly smaller - velocity amplitudes measured in Z-direction are only $30 \%$ lower than in X-direction.

2. Near train passage resulted in high-frequency registrations (average value: 97,2 Hz) while lowfrequency spectrum (average value: 17,6 Hz) was distinctive for far train passage (Fig. 4b). It is connected with substantial damping of the most frequent oscillations. There is no significant dependence between direction of surface wave propagation and variability of frequency.

3. Acceleration amplitudes estimated for proximate train are nearly 20-times higher than those calculated for distant train. It indicates on substantial damping, occurring in the first tens of meters nearby the source. It is mainly connected with attenuation of high-frequency vibrations $(>30 \mathrm{~Hz})$.

4. Calculated acceleration amplitude values of train-induced vibrations indicate for excess of safe values of vibration intensity. According to SWD classification, effects of vibrations are located in the $3^{\text {rd }}, 4^{\text {th }}$ and $5^{\text {th }}$ zone (Fig. 5), which implies "harmful effects on buildings" [18]. Basing on the Swiss Standard [20], the recorded level of ground motion is also unacceptable, especially for wooden and brickwork buildings (Fig. 6).

5. The results of field investigations can be considered to some extent as a contradiction of a notation in standard [18], that permits neglecting impacts of vibrations on building located further than $25 \mathrm{~m}$ away from railways. Field measurements demonstrated greater extent of potentially harmful vibration level, generated by cargo train. On the other hand, the SWD classification is dedicated for evaluation of construction oscillations. They are less intensive than measured values of ground motion, because of attenuation on the contact between a foundation and the subsoil. 


\section{REFERENCES}

1. H. Hao, T.C. Ang, J. Shen, "Building vibration to traffic-induced ground motion", Building and Environment, 36 : 321-336, 2001.

2. M. Crispino, M. D’apuzzo, "Measurement and prediction of traffic-induced vibration in a heritage building", Journal of Sound and Vibration, 246(2): 319-335, 2001.

3. B.H. Nam, J.Y. Kim, J.W. An, B.J. Kim, "A Review on the Effects of Earthborne Vibrations and the Mitigation Measures”, International Journal of Railway, 6(3): 95-106, 2013.

4. T. Krynicki, „Fale powierzchniowe i mikrosejsmiczne - nowe spojrzenie na ich znaczenie”, Biuletyn Informacyjny Przedsiębiorstwa Badań Geofizycznych 6: 43-63, 2007.

5. M.B. Shneerson, „Teoria i praktika naziemnoj niewzrywnoj sejsmorazwiedki” Praca zbiorowa. Wyd. Niedra, 1998.

6. H. Xia, Y. Cao, G. De Roeck, G. Degrande, "Environmental problems of vibrations induced by railway traffic", Frontiers of Architecture and Civil Engineering in China, 1(2): 142-152, 2007.

7. H. Xia, C. Jianguo, W. Pengbo, X. Chaoyi, G. De Roeck, G. Degrande, "Experimental investigation of railway traininduced vibrations of surrounding ground and a nearby multi-story building", Earthquake Engineering and Engineering Vibration, 8: 137-148, 2009.

8. H. Xia, Y.M. Cao, G. De Roeck, "Theoretical modeling and characteristic analysis of moving-train induced ground vibrations", Journal of Sound and Vibration, 329: 819-832, 2010.

9. H. Chebli, D. Clouteau, L. Schmitt, "Dynamic response of high-speed ballasted railway tracks: 3D periodic model and in situ measurements" Soil Dynamics and Earthquake Engineering, 28: 118-131, 2008.

10. H. Takemiya, "Analyses of wave field from high-speed train on viaduct at shallow/deep soft grounds" Journal of Sound and Vibration 310: 631-649, 2008.

11. Y. Zhang, N. Zhang, Y. Cao, Y. Yu, "A prediction model and its validation of railway-induced building vibrations", Advances in Mechanical Engineering, 8(10): 1-10, 2016.

12. G.R. Watts, V.V. Krylov., "Ground-borne vibration generated by vehicles crossing road humps and speed control cushions", Applied Acoustics, 59: 221-236, 2000.

13. G.A. Athanasopoulos, P.C. Pelekis, "Ground vibrations from sheetpile driving in urban environment: measurements, analysis and effects on buildings and occupants", Soil Dynamics and Earthquake Engineering, 19: 371-387, 2000.

14. Z. Sarnacka, Szczegółowa Mapa Geologiczna Polski 1:50 000, Arkusz Warszawa Wschód, Poland, 1979.

15. ABEM Instruments AB, “ABEM Terraloc Pro - User Manual”, Sweden, 2011.

16. A. Bąkowska, „Zachowanie się glin lodowcowych rejonu Warszawa-Służew pod wpływem obciążeń dynamicznych", PHD thesis, Warsaw University, Poland, 2009.

17. K. Kiełbasiński, „Geologiczno-inżynierska i geofizyczna ocena zachowania się gruntów spoistych w przekroju doliny Wisły wzdłuż Trasy Siekierkowskiej w Warszawie pod wpływem obciążeń dynamicznych”, PHD thesis, Warsaw University, Poland, 2014.

18. Polish Standard. PN-B-02170:2016-12: Evaluation of the harmfulness of building vibrations due to ground motion. Polish Committee of Normalization, Warsaw, 2016.

19. J. Studer, A. Suesstrunk, "Swiss Standard for Vibrational Damage to Buildings", In: Proceedings of the 10th International Conference on Soil Mechanics and Foundation Engineering. A.A., Balkema, Stockholm, 307-312, 1981.

20. Swiss Standard. SN 640 312: Effects of Vibration of Construction. Swiss Association of Standarization, Zurich, 1978.

\section{LIST OF FIGURES AND TABLES:}

Fig. 1. Location of measurement line [mapy.geoportal.gov.pl]

Rys. 1. Lokalizacja linii pomiarowej [mapy.geoportal.gov.pl]

Fig. 2. The arrangement of measuring set in relation to railway tracks, with imposed coordinate system

Rys. 2. Zastosowany układ pomiarowy odbiorników sejsmicznych, z przyjętym układem współrzędnych

Fig. 3. Records of vibration intensity from selected geophones - channels: 4, 5, 6, direction: X (particle velocity amplitude in $\mathrm{mm} / \mathrm{s}$ )

Rys. 3. Zapis intensywności drgań z wybranych geofonów - kanały 4., 5., 6., kierunek wzdłuż osi X (prędkość drgań cząstek gruntu w mm/s) 
Fig. 4. Comparison of measurement results between two passages of cargo train: a) near train, b) far train. Box plot values: minimum $-1^{\text {st }}$ quartile - median $-3^{\text {rd }}$ quartile - maximum

Rys. 4. Porównanie wyników pomiarów drgań dla przejazdów pociągu towarowego: a) po bliskim torze, b) po dalszym torze. Wizualizacja metodą box-plot (wartości): minimalna - 1. kwartyl - mediana 3. kwartyl - maksymalna

Fig. 5. Comparison of both train passages potential impact on buildings, according to Scale of Dynamic Effects adapted from Polish Standard [18]

Rys. 5. Ocena potencjalnego zagrożenia obiektów budowlanych spowodowanego przejazdem pociągów, na podstawie skali SWD, za Polską Normą [18]

Fig. 6. Comparison of both train passages potential impact on buildings, on the background of classification, adapted from Swiss Standard [20]

Rys. 6. Ocena potencjalnego zagrożenia obiektów budowlanych spowodowanego przejazdem pociągów, na podstawie Normy Szwajcarskiej [20] 


\title{
INTENSYWNOŚĆ DRGAŃ PODŁOŻA GRUNTOWEGO SPOWODOWANYCH RUCHEM POCIĄGÓW W REJONIE DWORCA KOLEJOWEGO WARSZAWA-REMBERTÓW W ŚWIETLE KLASYFIKACJI NORMOWYCH
}

\author{
Słowa kluczowe: ruch kolejowy, Skala Wpływów Dynamicznych, intensywność drgań podłoża gruntowego, fale \\ powierzchniowe, Norma Szwajcarska
}

\section{STRESZCZENIE:}

Jednym z najbardziej znaczących spośród antropogenicznych źródeł drgań, generowanych w obrębie obszarów zurbanizowanych, jest transport szynowy. Przenoszenie energii w postaci wibracji podłoża zachodzi głównie poprzez propagację fal powierzchniowych. Niniejsze opracowanie dotyczy pomiarów drgań podłoża, indukowanych przejazdem pociągów towarowych w rejonie dworca kolejowego Warszawa-Rembertów. Celem przeprowadzonych badań było określenie intensywności tych drgań, poprzez obliczenie ich amplitudy, przyspieszenia oraz częstotliwości. Przeprowadzone analizy dotyczyły przejazdów dwóch pociągów towarowych, przemieszczających się w różnej odległości względem wytyczonej linii pomiarowej.

Układ pomiarowy składał się z sejsmografu ABEM Terraloc Pro wraz z podłączonym kablem pomiarowym, i 24 odbiorników sejsmicznych (geofonów). Linia pomiarowa o długości 35 m została rozstawiona równolegle względem torów kolejowych, w odległości $7 \mathrm{~m}$ od pierwszego toru. Odbiorniki zostały podzielone na 8 grup po 3 geofony w każdej, a kolejne grupy były podłączane w odległości $5 \mathrm{~m}$ od poprzedniej. W obrębie każdej grupy podłączano kolejno geofony rejestrujące drgania: (1) w płaszczyźnie poziomej, w kierunku prostopadłym względem linii kolejowej, (2) w płaszczyźnie poziomej, równolegle względem linii kolejowej, (3) w płaszczyźnie pionowej. Dla każdej grupy założono lokalny układ współrzędnych kartezjańskich (X, Y, Z), którego osie zostały ustawione zgodnie z kierunkami rejestracji drgań przez odbiorniki sejsmiczne.

Zapisy wibracji gruntu były przetwarzane z zastosowaniem oprogramowania: Reflex 2D-Quick oraz Reflexw, które umożliwia określenie amplitudy prędkości drgań w dziedzinie czasu oraz wykonanie transformaty Fouriera (FFT) dla przedstawienia spektrum częstotliwości. Analizę danych przeprowadzono zgodnie z metodyką peak particle velocity (PPV) - maksymalnych amplitud prędkości drgań, na postawie której dla każdego zapisu na odbiorniku sejsmicznym, wybierano impuls o największej amplitudzie prędkości drgań wraz z odpowiadającą jej częstotliwością. Przy założeniu harmonicznego charakteru oscylacji, dokonano obliczeń amplitudy przemieszczenia i amplitudy przyspieszenia. Operacji tych dokonano z rozróżnieniem kierunku rejestracji drgań przez odbiorniki sejsmiczne (X, Y, Z).

Wyniki badań opracowano dla przemieszczania się dwóch pociągów towarowych: (1) przejazd pociągu po najbliższym torze - w odległości $7 \mathrm{~m}$ od linii pomiarowej, (2) przejazd pociągu po dalszym torze $-25 \mathrm{~m}$ od linii pomiarowej. Dla każdego z przejazdów wykonano dwie rejestracje, co przy 24 odbiornikach pozwoliło na uzyskanie 16 wartości w każdym z trzech kierunków rejestracji drgań, dla każdego przejazdu pociągu towarowego. Wyniki pomiarów wskazują na znacząco wyższą intensywność wibracji wzbudzonych przejazdem bliższego pociągu, w stosunku do przejazdu pociągu dalszego. Pod względem prędkości drgań, stosunek ten wynosi odpowiednio (średnia dla trzech kierunków): 35,2 mm/s do $7,1 \mathrm{~mm} / \mathrm{s}$, a dla częstotliwości: $97,2 \mathrm{~Hz}$ do 17,6 Hz. Wynikające z obliczeń uśrednione amplitudy przyjmują zbliżone wartości: $0,061 \mathrm{~mm}$ do $0,075 \mathrm{~mm}$, natomiast obliczone przyspieszenia drgań cząstek gruntu są o rząd wielkości większe dla przejazdu pociągu w bliskiej odległości: $2,13 \mathrm{~g}$, wobec $0,09 \mathrm{~g}$ dla dalszego przejazdu. Ponadto, oscylacje zarejestrowane dla bliskiego przejazdu, wykazują znaczący poziom zróżnicowania w zależności od płaszczyzny i 
kierunku propagacji generowanej fali powierzchniowej. Ich intensywność w kierunku prostopadłym względem linii kolejowej jest ponad dwukrotnie większa niż w płaszczyźnie pionowej.

Obliczone wartości amplitudy przyspieszenia wraz z odpowiadającymi im częstotliwościom drgań zostały przedstawione na tle Skali Wpływów Dynamicznych (SWD-II, PN-02170:2016-12). Rozkład punktów określających intensywność drgań wzbudzonych przejazdem pociągu po bliższym torze wskazuje na przynależność do IV i V strefy, co oznacza potencjalnie znaczące uszkodzenia konstrukcji podlegającej wpływowi takich wibracji. Oscylacje zarejestrowane dla przejazdu pociągu po dalszym torze mieszczą się głównie w obrębie strefy III, co oznacza możliwość wystąpienia niewielkich uszkodzeń konstrukcji. W Polskiej Normie określono, że w odległości większej niż 25 m od linii kolejowej wpływ drgań na budynek można pominąć. Wyniki powyższych badań stanowią przesłankę, że zasięg wibracji szkodliwych dla konstrukcji obiektów budowlanych może być znacząco większy.

W przypadku Normy Szwajcarskiej, linie graniczne dopuszczalnej intensywności drgań w przestrzeni: prędkość/częstotliwość, wytyczone są dla budynków w zależności od ich konstrukcji. Każda z tych linii w przybliżeniu odpowiada dolnej granicy dla strefy III w PN-02170:2016-12. Przeprowadzona analiza pozwala ocenić, że intensywność zarejestrowanych drgań jest szkodliwa dla konstrukcji drewnianych oraz murowanych, a w przypadku bliskiego przejazdu pociągu - nawet dla wzmocnionych konstrukcji żelbetowych. Z porównania zapisów dwóch norm wynika, że Norma Szwajcarska zachowuje większą ostrożność w przewidywaniu wpływu drgań na obiekty budowlane. 